\title{
PALEOCLIMATIC IMPLICATIONS OF RADIOCARBON DATING OF SPELEOTHEMS FROM THE CRACOW-WIELUŃ UPLAND, SOUTHERN POLAND
}

\author{
ANNA PAZDUR, MIECZYS ŁAW F. PAZDUR, ${ }^{1}$ JACEK PAWLYTA, \\ Radiocarbon Laboratory, Silesian Technical University, Gliwice, Krzywoustego 2, \\ PL-44-100 Gliwice, Poland
}

ANDRZEJ GORNY and MICHA

Geological Museum, Academy of Mining and Metallurgy, Mickiewicza 30,
PL-30-059 Cracow, Poland

\begin{abstract}
We report preliminary results of a long-term systematic study intended to gather paleoclimatic records from precisely dated speleothems. The research project is limited to speleothems deposited in caves of the Cracow-Wielun Upland, the largest and best-explored karst region in Poland, covering ca. $2900 \mathrm{~km}^{2}$ with $>1000$ caves. Speleothem samples were selected from collections of the Geological Museum of the Academy of Mining and Metallurgy in Cracow. Radiocarbon dates of these samples from ca. 45-20 ka BP almost exactly coincide with age range of the Interplenivistulian. A break in speleothem formation between $c a .20$ and $10 \mathrm{ka} \mathrm{BP}$ may be interpreted as a result of serious climatic deterioration associated with the maximum extent of the last glaciation. We observed differences among ${ }^{14} \mathrm{C}, \mathrm{U} / \mathrm{Th}$ and $\mathrm{AAR}$ dating results. Changes of $\delta^{13} \mathrm{C}$ and $\delta^{18} \mathrm{O}$ in speleothems that grew between $c a .30$ and $20 \mathrm{ka}$ BP may be interpreted as changes of paleoclimatic conditions.
\end{abstract}

\section{INTRODUCTION}

It is well known that speleothems formed during relatively warm and humid periods, their growth seriously stunted during the glacial periods (Baker, Smart and Ford 1993; Dorale et al. 1992; Geyh and Hennig 1986; Geyh and Schleicher 1990; Hennig, Grün and Brunnacker 1983). Thus, the presence or absence of speleothems of a certain age is an important indicator of paleoclimatic conditions. Detailed studies of isotopic changes recorded in appropriately selected speleothems are an effective tool for reconstructing subtle climate changes in the moderate zone (Gascoyne 1992; Geyh and Hennig 1986; Harmon et al. 1978). Speleothem growth rate depends on the intensity of water inflow during precipitation and because of this depends on humidity (Dreybrodt 1988; Duliński and Różański 1990).

We present here preliminary results from the first stage of our long-term systematic study of isotopic data gathered from speleothem records precisely dated by radiocarbon $\left({ }^{14} \mathrm{C}\right)$ and other dating methods, including uranium/thorium (U/Th) and thermoluminescence/electron spin resonance (TL/ESR). The main aim of this preliminary stage was to gather the necessary introductory information concerning the age of speleothems deposited in caves of southern Poland.

\section{STUDY AREA}

For this project, we chose to study speleothems deposited in caves of the Cracow-Wielun Upland, the largest and best-explored karst region in Poland, extending from Cracow in the south to Wielun, ca. $160 \mathrm{~km}$ north of Cracow. The Cracow-Wielun Upland consists of Upper Jurassic limestones and covers $c a .2900 \mathrm{~km}^{2}$. More than 1000 caves are located in this area. Most of the caves are relatively small; only two are longer than $500 \mathrm{~m}$ and 66 longer than $100 \mathrm{~m}$ (Szelerewicz and Górny 1986; Wiśniewski 1981). Many caves were inhabited during the Middle and Upper Paleolithic (Madeyska 1982) and then during the Mesolithic and Neolithic. Figure 1 shows the localities of some of the most important caves in the Cracow-Wielun Upland.

${ }^{1}$ Deceased 11 May 1995

Proceedings of the 15th International ${ }^{14}$ C Conference, edited by G. T. Cook, D. D. Harkness,

B. F. Miller and E. M. Scott. RADIOCARBON, Vol. 37, No. 2, 1995, P. 103-110 


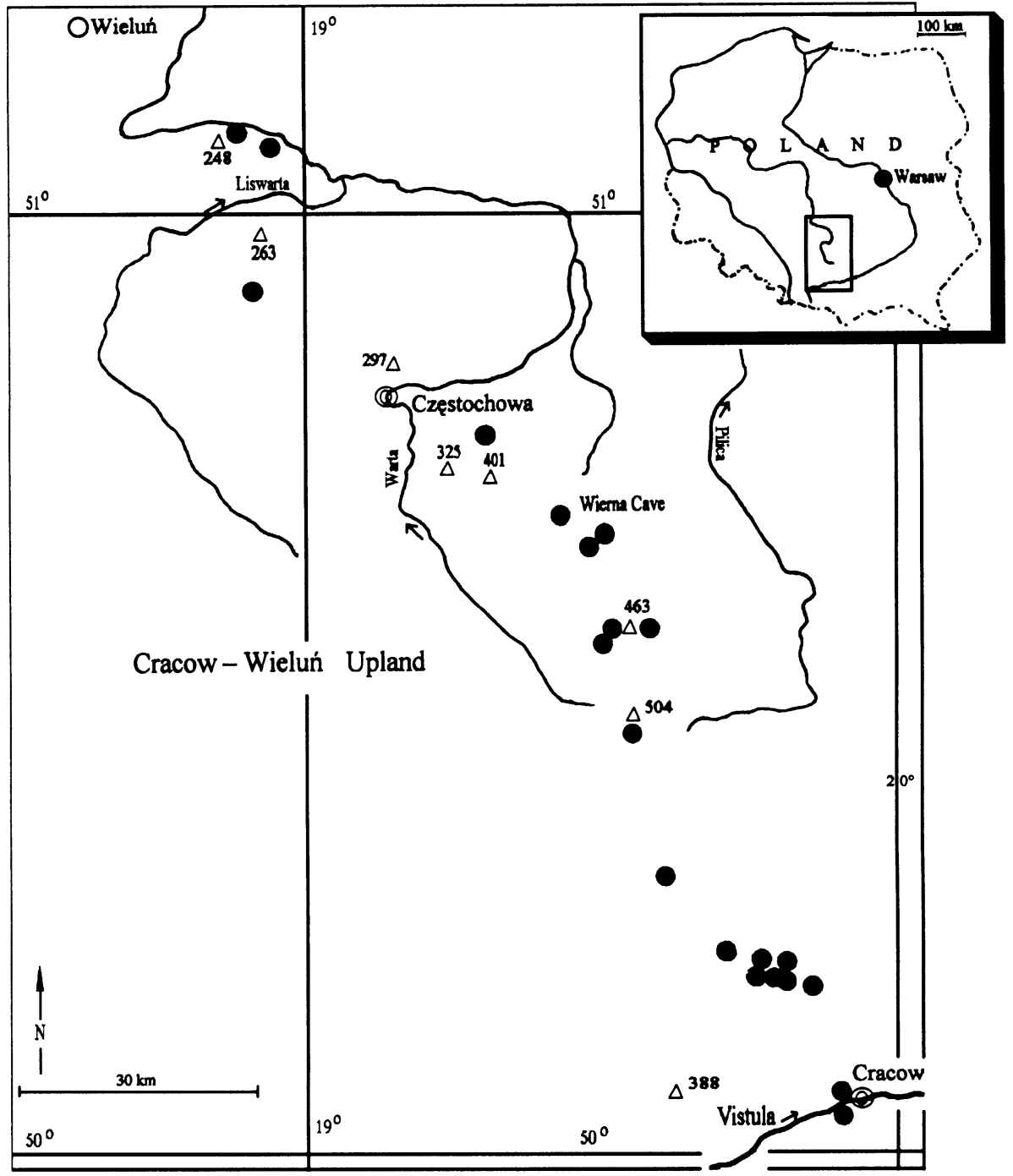

Fig. 1. Map of the Cracow-Wielun Upland with locations of the largest caves included in this study. $\bullet=$ locations of the largest caves; $0=$ important cities; $\Delta=$ major hills (figures denote elevation in meters above sea level (asl)).

\section{METHODS}

The speleothems and flowstones used in our study were relatively small. Oblong speleothems measured $<20-30 \mathrm{~cm}$ and transversal dimensions were $<15 \mathrm{~cm}$. The largest stalagmite, JWi2 from Wierna Cave, shown in Figure 2, is $30 \mathrm{~cm}$ long, with a basal diameter $c a .10 \mathrm{~cm}$; the largest flowstone was ca. $20 \times 30 \mathrm{~cm}$.

Speleothems were subdivided according to lithological features; the main indicators for separating samples for dating were surfaces indicating a break in calcite deposition. As a rule, the outermost layers were dated to determine termination of calcite deposition. If appropriate, the oldest layers were used for ${ }^{14} \mathrm{C}$ dating. 


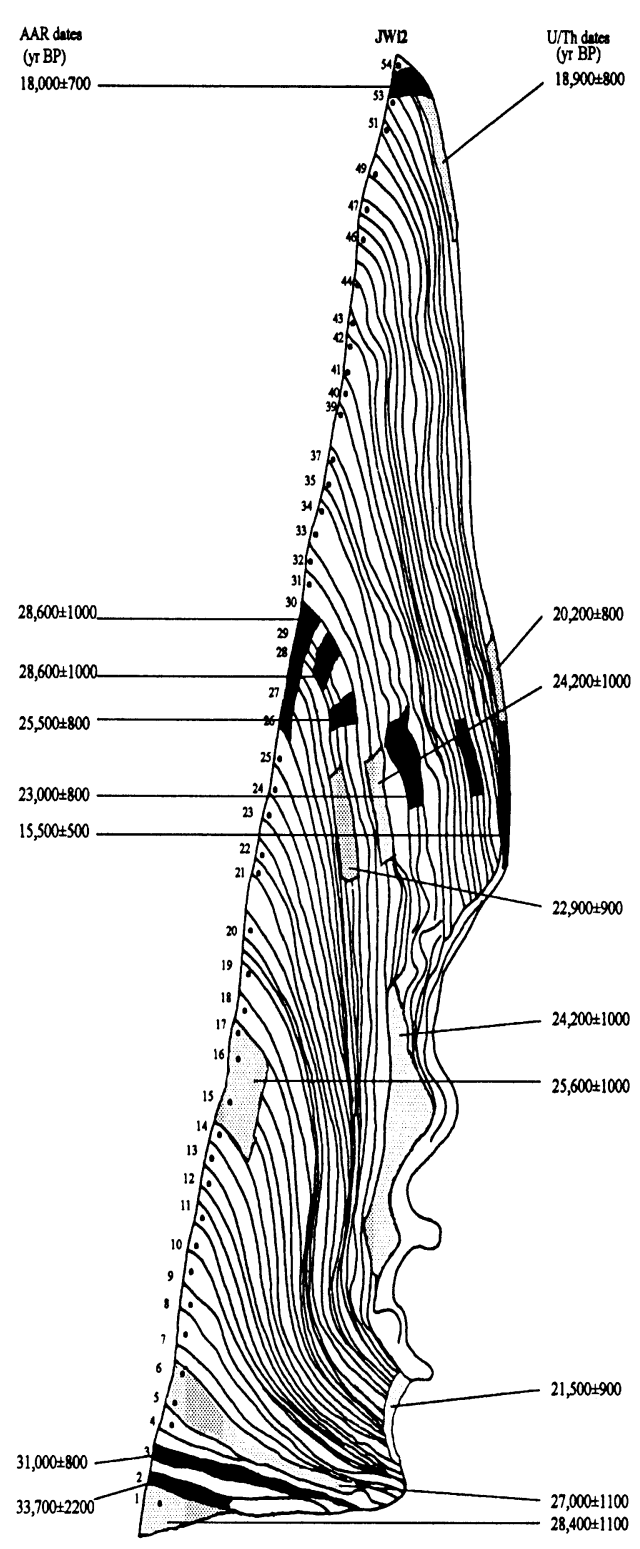

Fig. 2. Cross-section through stalagmite JWi2 from Wierna Cave, showing sampling points for stable carbon and oxygen isotope measurements (numbered dots along the growth axis) and results of U/Th (®)and AAR ( $\square$ ) dating.
Calcite was treated with hydrochloric acid, and evolved $\mathrm{CO}_{2}$ was purified, stored in glass reservoirs for at least one month to allow for complete decay of ${ }^{222} \mathrm{Rn}$ and then counted in proportional counters filled with pure $\mathrm{CO}_{2}$ (Pazdur and Pazdur 1986). Small aliquots of $\mathrm{CO}_{2}$ were used for massspectrometric determinations of $\delta^{13} \mathrm{C}$ and $\delta^{18} \mathrm{O}$. We investigated 89 speleothems from 41 caves and obtained $170{ }^{14} \mathrm{C}$ dates; 45 of these samples yielded infinite dates.

Speleothem JWi2 (Fig. 2) underwent U/Th and amino acid racemization (AAR) dating at the Institute of Geochemistry and Physics of Minerals of the Ukrainian Academy of Sciences in Kiev. AAR results were based on experimentally determined relations between stable and unstable amino acids, Thr/Leu and Thr/Glu.

Samples for stable oxygen and carbon isotope $\left(\delta^{18} \mathrm{O}\right.$ and $\left.\delta^{13} \mathrm{C}\right)$ analysis were taken by drilling $2-\mathrm{mm}$ apertures of $10-\mathrm{mm}$ long along a growth line as shown in Figure 2 . The weight of each sample was $c a .30 \mathrm{mg}$. The stable isotope analyses were performed in Kiev.

\section{RESUlts}

\section{Age Distribution of Speleothems from the Study Area}

The large number of dating results obtained by different methods enables us to interpret results using probabilistic methods (Baker, Smart and Ford 1993; Geyh 1970; Smart and Richards 1992; Srdoc et al. 1983). Frequency distributions of dates may be compared with results of investigations obtained by other methods, such as changes in temperature and precipitation in the past reconstructed from pollen analyses of peatbog profiles and lake sediments of unglaciated areas, and with paleoclimatic records from deep sea cores (Guiot et al. 1989; Martinson et al. 1987; Shackleton 1969).

Our first results enable us to draw some preliminary conclusions about climate changes in the study area during the last glacial-interglacial cycle (Pazdur et al. 1994). Figures 3 and 4 show the main set of ${ }^{14} \mathrm{C}$ results as probability distributions. The ${ }^{14} \mathrm{C}$ dates reported here are conventional ages calcu- 

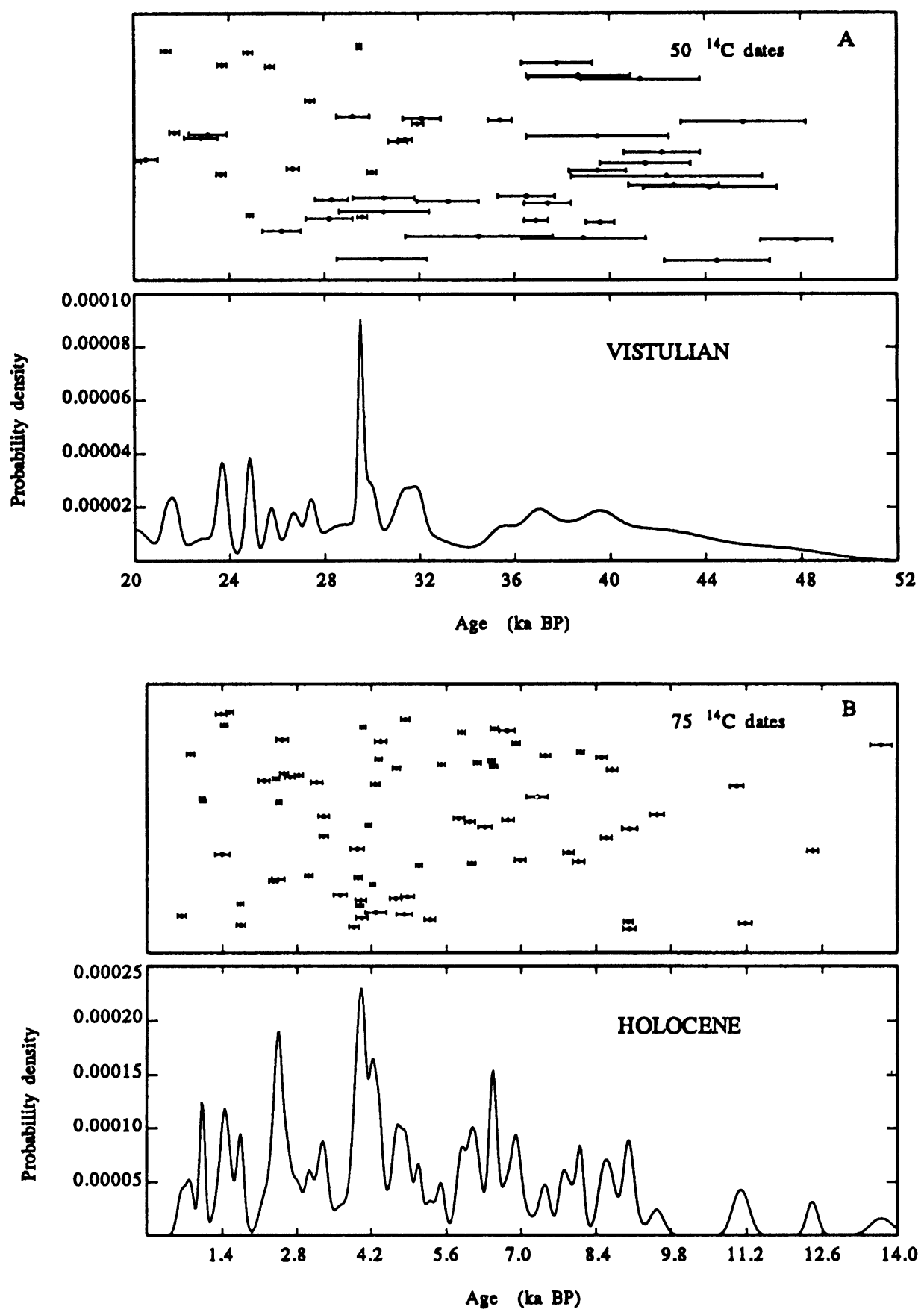

Fig. 3. Conventional ${ }^{14} \mathrm{C}$ dates of speleothems (uncorrected for reservoir effect). A. Vistulian; B. Holocene.

lated according to Stuiver and Polach (1977). We did not calculate the reservoir age correction, which we assume to be $1500 \mathrm{yr}$, because the ${ }^{14} \mathrm{C}$ ages seem to be $1500 \mathrm{yr}$ too old (Geyh 1970; Geyh and Hennig 1986). 


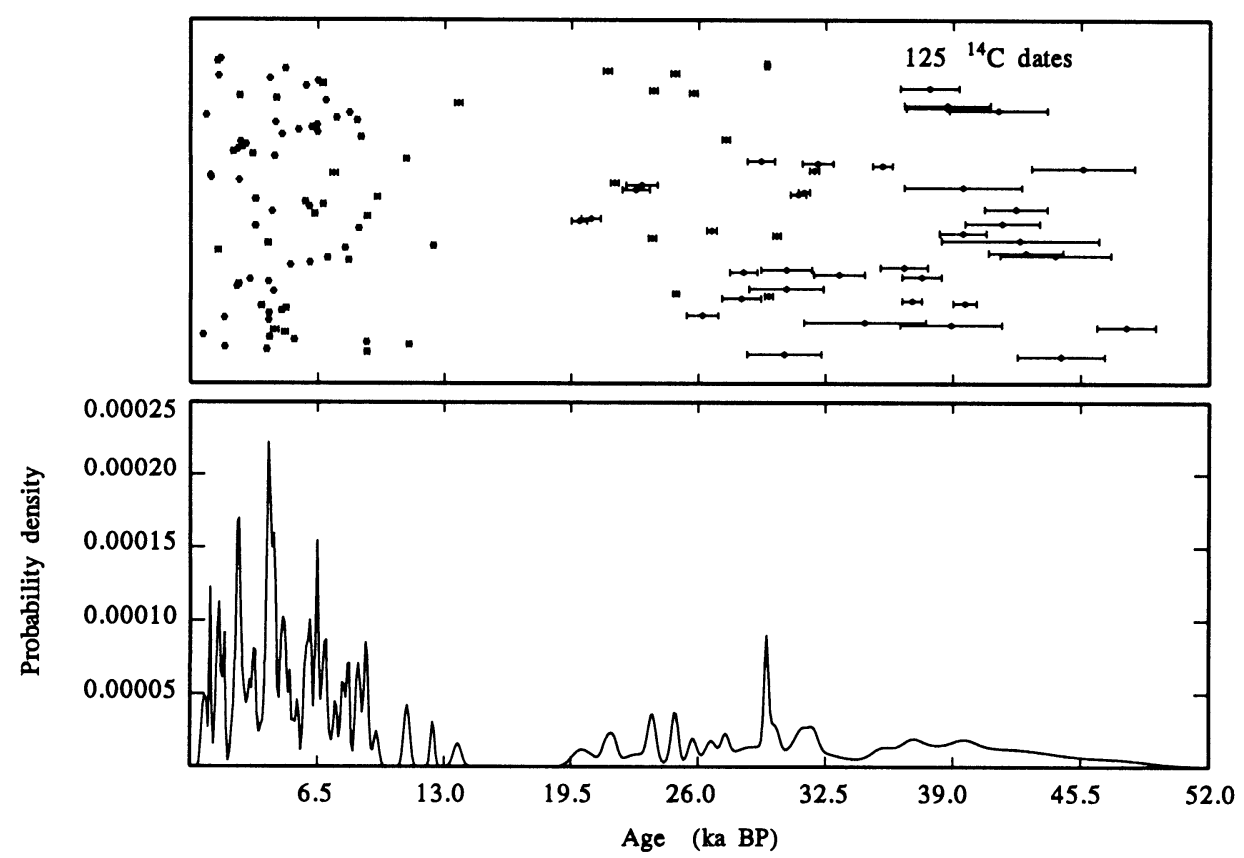

Fig. 4. Conventional ${ }^{14} \mathrm{C}$ dates of all dated speleothem samples (uncorrected for reservoir effect).

The group of older dates range from 48 to $20 \mathrm{ka}$ BP (Fig. 3B). These boundaries, determined by the presence of speleothems, coincide almost exactly with the Interplenivistulian climatostratigraphic unit, determined from paleogeographical studies in the foothills of the Carpathian Mountains (Starkel 1980). This period approximately parallels the duration of the Jerzmanowice culture, discovered at numerous sites in the Jerzmanowice area (Madeyska 1982). Unfortunately, the contamination effect is important for samples with ages of $>30 \mathrm{ka}$ (Srdoc et al. 1986), and it is possible that many samples attributed to the Interplenivistulian have ages far beyond the limits of ${ }^{14} \mathrm{C}$ dating.

Our results also show an interruption in speleothem formation between 20 and $10 \mathrm{ka}$ BP, which may be interpreted as serious climatic deterioration associated with the maximum extent of the last glaciation (Younger Plenivistulian, incorporating the Late Glacial period). A single date, $13,700 \pm 200 \mathrm{BP}$, (Gd-6435), obtained from the thin outermost layer of flowstone collected in the Wierzchowska Górna Cave, may suggest that a relatively warm climate, suitable for speleothem formation in southern Poland, occurred before the beginning of the Holocene, probably during the Bølling/Allerød interstadial. Of course, a single result must be confirmed by dates from other caves in the study area before conclusions can be drawn.

The principal period of speleothem deposition falls within the Holocene (Fig. 3B). The oldest dates of this group, at $9000 \mathrm{BP}$, were obtained on speleothems from the Ciemna and Straszykowa Caves. In particular, the maximum peak of the date density plots (Figs. 3B and 4) approximately fit the climatic optimum of the Holocene, i.e., the Atlantic period.

\section{Age of Speleothem JWi2}

Almost identical U/Th $(18,900 \pm 800 \mathrm{BP})$ and AAR dates $(18,000 \pm 700 \mathrm{BP})$ of the outermost layer of stalagmite JWi2 (Fig. 2) indicate that deposition ceased just before the last glacial maximum, the socalled Leszno phase, dated in other records from Poland to ca. 18 ka BP (Kozarski 1980; Mojski 1992; 
JWi2

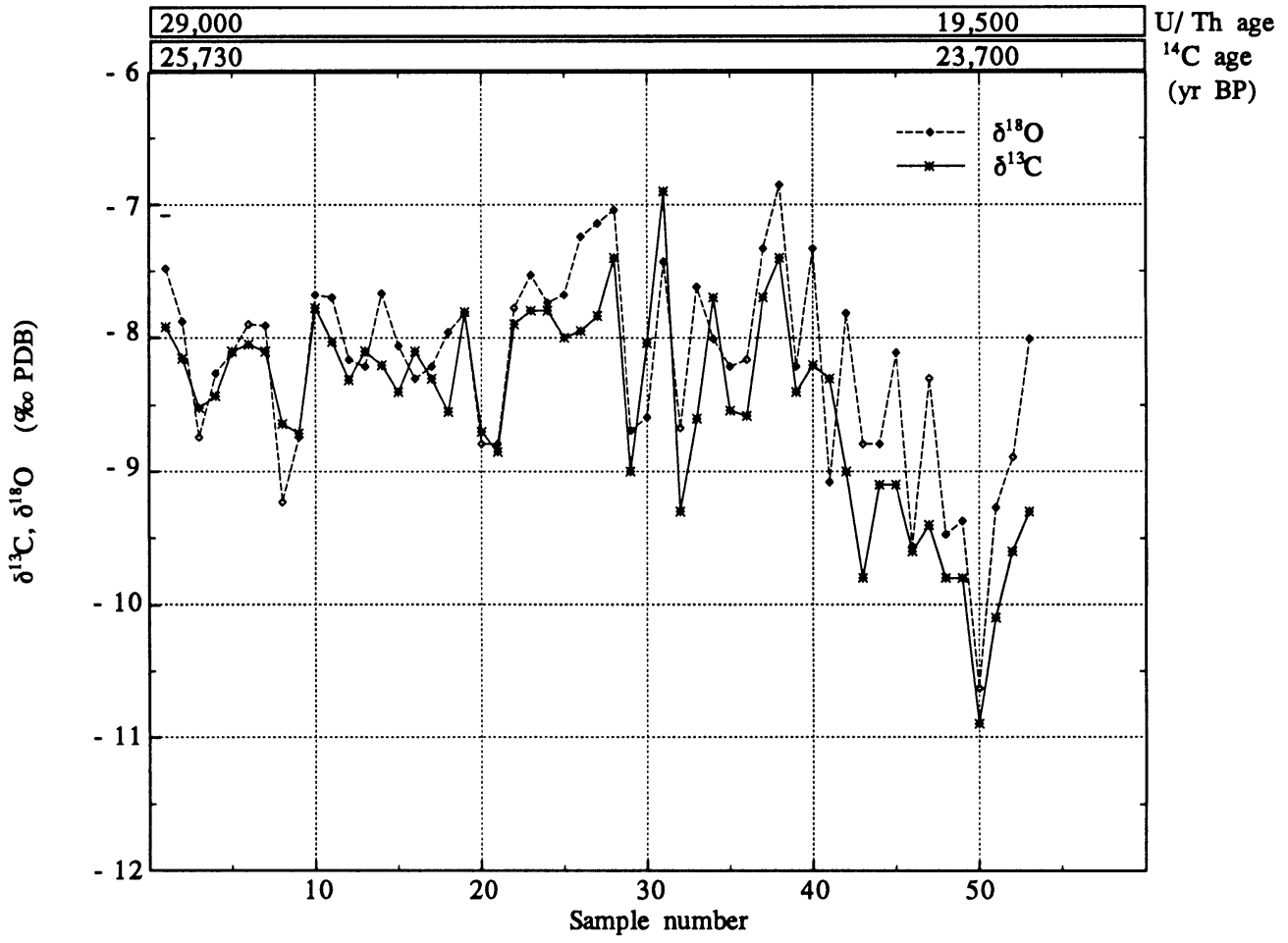

Fig. 5. Stable carbon and oxygen isotope measurements in stalagmite JWi2 along its growth line. U/Th dates were obtained independently from dates listed in Figure 2.

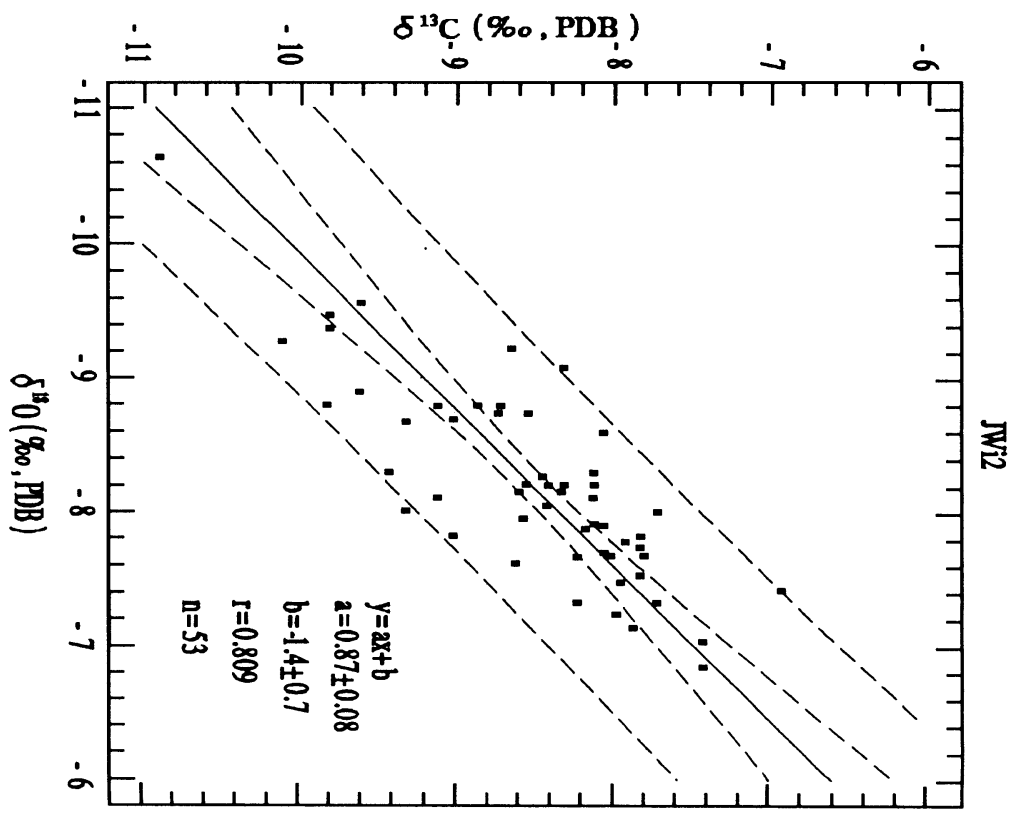

Fig. 6. Correlation between $\delta^{13} \mathrm{C}$ and $\delta^{18} \mathrm{O}$ measured along the growth axis of stalagmite JWi2. $---=1-$ and $2-\sigma$ ranges of approximation uncertainties. 
Starkel 1988). A conventional ${ }^{14} \mathrm{C}$ date obtained for the outermost layer is much older $(23,700 \pm$ $200 \mathrm{BP})$. The three methods of dating have yielded different results for the beginning of stalagmite's growth. U/Th $(28,400 \pm 1100 \mathrm{BP})$ and AAR $(33,700 \pm 2200 \mathrm{BP})$ dates are much older than the corresponding ${ }^{14} \mathrm{C}$ date $(25,730 \pm 200 \mathrm{BP})$. Because the study has not been completed, however, it is difficult to be definitive about the discrepancies. Diagenetic processes may be the major source of age differences (Geyh and Henning 1986; Chen and Polach 1986; Yates 1986; Fontes et al. 1992).

\section{Stable Isotope Analysis of Speleothem JWi2}

Figure 5 shows the results of $\delta^{13} \mathrm{C}$ and $\delta^{18} \mathrm{O}$ measurements on JWi2. The rapid decline of both curves at the end of speleothem formation (before $c a .18,000 \mathrm{BP}$ ) may relate to the rapid cooling before the last glaciation in Central Europe observed in different paleoclimatic records (Mojski 1992). It is interesting to note more negative values of both $\delta^{13} \mathrm{C}$ and $\delta^{18} \mathrm{O}$ when the temperature falls. Figure 6 shows a strong positive correlation between $\delta^{13} \mathrm{C}$ and $\delta^{18} \mathrm{O}$ values: the correlation coefficient $\mathrm{r}=0.809$ ( $\mathrm{n}=53$ points). Of the $\delta^{13} \mathrm{C}$ and $\delta^{18} \mathrm{O}$ values that we measured along five layers, we observed positive, negative and near-zero correlation coefficients. It seems that speleothem was deposited under conditions of kinetic isotope fractionation.

\section{CONCLUSION}

A group of older ${ }^{14} \mathrm{C}$ dates, obtained on speleothem samples from 18 caves, range from 45 to $20 \mathrm{ka}$ BP. This time frame, determined by the presence of speleothems, coincides almost exactly with the interval of the Interplenivistulian. An interruption occurred in speleothem formation between 20 and $10 \mathrm{ka}$ BP, caused by serious climatic deterioration associated with the last glacial maximum. The younger dates span the Holocene, the broad maximum falling within the Atlantic phase.

${ }^{14} \mathrm{C}, \mathrm{U} / \mathrm{Th}$ and $\mathrm{AAR}$ dates were obtained on a single speleothem from Wierna Cave (JWi2). These, accompanied by $\delta^{13} \mathrm{C}$ and $\delta^{18} \mathrm{O}$ values obtained along its growth line, indicate a rapid cooling before speleothem JWi2 stopped growing ( $c a .18 \mathrm{ka} \mathrm{BP}$ ).

\section{ACKNOWLEDGMENT}

This study was financially supported by grant PB 740/6/91 from the Committee for Scientific Research, Poland.

\section{REFERENCES}

Baker, A., Smart, P. L. and Ford, D. C. 1993 Northwest European paleoclimate as indicated by growth frequency variations of secondary calcite deposits. Palaeogeography, Palaeoclimatology, Palaeoecology 100: 291-301.

Chen, Y. and Polach, H. 1986 Validity of ${ }^{14} \mathrm{C}$ ages of carbonates in sediments. In Stuiver, M. and Kra, R. S., eds., Proceedings of the 12 th International ${ }^{14} \mathrm{C}$ Conference. Radiocarbon 28(2A): 464-472.

Dorale, J. A., Gonzales, L. A., Reagan, M. K., Pickett, D. A., Murell, M. T. and Baker, R. G. 1992 A high-resolution record of Holocene climate change in speleothem calcite from Cold Water Cave, northeast Iowa. Science 258: 1626-1630.

Dreybrodt, W. 1988 Processes in Karst System: Physics, Chemistry and Geology. Berlin, Springer-Verlag: 288p.

Duliński, M. and Różański, K. 1990 Formation of ${ }^{13} \mathrm{C} /$
${ }^{12} \mathrm{C}$ ratios in speleothems: A semi-dynamic model. Radiocarbon 32(1): 7-16.

Fontes, J. C., Andrews, J. N., Causse, C. and Gibert, E. 1992 A comparison of radiocarbon and $U / T h$ ages on continental carbonates. In Long, A. and Kra, R. S., eds., Proceedings of the 14 th International ${ }^{14} \mathrm{C}$ Conference. Radiocarbon 34(3): 602-610.

Gascoyne, M. 1992 Palaeoclimate determination from cave calcite deposits. Quaternary Sciences Reviews 11: 609-63

Geyh, M. A. 1970 Zeitliche Abgrenzung von Klimaanderungen mit C-14 Daten von Kalksinter und organischen Substanzen. Geologisches Jahrbuch 98: 15-22.

Geyh, M. A. and Hennig, G. J. 1986 Multiple dating of a long flowstone profile. In Stuiver, M. and Kra, R. S., eds., Proceedings of the 12 th International ${ }^{14} \mathrm{C}$ Conference. Radiocarbon 28(2A): 503-509. 
Geyh, M. A. and Schleicher, H. 1990 Absolute Age Determination: Physical and Chemical Dating Methods and Their Application. Berlin-Heidelberg, SpringerVerlag: $503 \mathrm{p}$.

Guiot, J., Pons, A., Beaulieu, J. L. and Reille, M. 1989 A 140,000 year continental climate reconstruction from two European pollen records. Nature 338: 309-313.

Harmon, R. S., Thompson, P., Schwarcz, H. P. and Ford, D. C. 1978 Late Pleistocene paleoclimates of North America as inferred from stable isotope studies of speleothems. Quaternary Research 9: 54-70.

Hennig, G. J., Grün, R. and Brunnacker, K. 1983 Speleothems, travertines and paleoclimates. Quaternary Research 20: 1-29.

Kozarski, S. 1980 An outline of Vistulian stratigraphy and chronology of the Great Poland Lowland. Quaternary Studies in Poland 2: 21-35.

Madeyska, T. 1982 The stratigraphy of Palaeolithic sites of the Cracow Upland. Acta Geologica Polonica 32: 227-242.

Martinson, D. G., Pisias, N. G., Hays, J. D., Imbrie, J., Moore, T. C. and Shackleton, J. 1987 Age dating and the orbital theory of the ice ages: Development of a high-resolution 0 to 300,000 year chronostratigraphy. Quaternary Research 27: 1-29.

Mojski, J. E. 1992 Vistulian stratigraphy and TL dates in Poland. In Robertson, A. M., Ringberg, B., Miller, U. and Brunnberg, L., eds., Quaternary Stratigraphy, Glacial Morphology and Environmental Changes. Uppsala, Geological Survey of Sweden: 195-200.

Pazdur, A. and Pazdur, M. F. 1986 The measuring equip ment of the Gliwice Radiocarbon Laboratory. Zeszyty Naukowe Politechniki Ślqskiej, Seria MatematykaFizyka, Z. 46, Geochronometria 1: 55-69 (in Polish).

Pazdur, A., Pazdur, M. F., Hercman, H., Górny, A. and Olszewski, M. 1994 Preliminary results of the studies on the chronology of speleothem deposition in selected caves of the Cracow-Wielun Upland. Zeszyty
Naukowe Politechniki Ślqskiej, Seria MatematykaFizyka, Z. 71, Geochronometria 10: 61-79 (in Polish). Shackleton, N. J. 1969 The last interglacial in the marine and terrestrial records. Philosophical Transactions of the Royal Society, Series B 174: 135-154.

Smart, P. L. and Richards, D. 1992 Age estimates for the late Quaternary sea-stands. Quaternary Sciences Reviews 11: 687-696.

Srdoč, D., Horvatinčc, N., Obelic, B., Krajcar-Bronic, I. and O'Malley, P. 1986 The effects of contamination of calcareous sediments on their radiocarbon ages. In Stuiver, M. and Kra, R. S., eds., Proceedings of the 12th International ${ }^{14} \mathrm{C}$ Conference. Radiocarbon 28 (2A): 510-514.

Srdoc, D., Horvatinzič, N., Obelic, B. and Sliep̌̌ević, A. 1983 Radiocarbon dating of tufa in paleoclimatic studies. In Stuiver, M. and Kra, R. S., eds., Proceedings of the 11 th International ${ }^{14} \mathrm{C}$ Conference. Radiocarbon 25(2): 421-427.

Stuiver, M. and Polach, H. 1977 Discussion: Reporting of ${ }^{14} \mathrm{C}$ data. Radiocarbon 19(3): 355-363.

Starkel, L. 1980 Stratigraphy and chronology of the Vistulian in the Polish Carpathians and in the Subcarpathian Basins. Quaternary Studies in Poland 2: 121135.

Starkel, L. 1988 Remarks on the Quaternary stratigraphy of the Polish Carpatians and their foreland. Quaternary Studies in Poland 8: 49-59.

Szelerewicz, M. and Gorny, A. 1986 Caves of the Cracow-Wieluń Upland. Warsaw and Cracow, PTTK Kraj (in Polish).

Wiśniewski, W. W. 1989 Polish caves in numbers. Eksplorancik 1-3: 9-12 (in Polish).

Yates, T. 1986 Studies of non-marine mollusks for the selection of shell samples for radiocarbon dating. In Stuiver, M. and Kra, R. S., eds., Proceedings of the 12th International ${ }^{14} \mathrm{C}$ Conference. Radiocarbon 28 (2A): $457-463$. 